\title{
GOOD GOVERNANCE AND THE RULE OF LAW
}

\author{
Nik Ahmad Kamal Nik Mahmod \\ International Islamic University Malaysia
}

\begin{abstract}
Good governance is basically governing in the right and just ways. Good governance relates to good administration at both public and private sectors. Corporate governance is synonymous and the common usage in the private sector. Common characteristics of good governance include transparency, accountability, participatory and rule of law. Rule of law is the focus of this paper. The principle in itself is problematic because of multifarious interpretation Nonetheless, the consensus has been that rule of law is essential in any government and breach of its principles may lead to arbitrariness and breach of fundamental rights. The paper will expound the roles of rule of law in ensuring good governance and how abuse of power and corruption have undermined rule of law seriously and subsequently affect good governance.
\end{abstract}

\section{Introduction}

The United Nations Economic and Social Commission for Asia and the Pacific (UNESCAP) defined 'governance' as the process of decision-making and the process by which decisions are implemented (or not implemented) (UNESCAP, 2013). Thus 'good governance' is the process that has fulfilled or in accordance with certain characteristics deemed appropriate or standard recognized and accepted by international bodies such as the UN. UNESCAP itself laid down eight (8) characteristics. Generally agreed characteristics of good governance include accountability, transparent, follows the rule of law, responsive, equitable and inclusive, effective and efficient, and participatory.

Accountability refers to the government being responsible and answerable to its decisions and actions. Transparent in the government process is known and clear in procedure and undertakings. People are able to see how and why decision is made. Rule of law in good 
governance means that there is legal framework that establishes and provides power to the government. Rules and regulations are clear in providing powers and jurisdiction to the authorities. Responsiveness means that the government is serving the needs of the community and also trying to balance out the competing interest in the community and always responsive to their demands and needs. Equitable and inclusive in good governance is equal treatment is given to people in all walk of life and the government is giving special consideration to the needy while proving the opportunity to many to participate in decision making process. Effective and efficient is the optimal utilization of resources while ensuring wastages are reduced as much as possible. Participatory process is giving opportunity to take part for those who are interested in the process of decision making through consultation and indirect involvement such as debate, town hall meetings, consultative papers and memorandum. It is basically the government getting opinions from the public before drafting, passing law and deciding as well as implementing policies.

The paper will focus on the role of the rule of law in good governance and how corruption and breaches of rule of law has undermined the principle; and the importance of rule of law to ensure that good governance is promoted and practiced to provide the best services to the people.

\section{Rule of Law}

Rule of law is non-arbitrary governance as opposed to one based on the power and whim of an absolute ruler (United Nations, 2013). It is very much linked to principle justice and negation of absolute power and discretion. Rule of law is now embedded in the United Nation's Charter. In its Preamble, one of the aims of the United Nations is:

To establish conditions under which justice and respect for the obligations arising from treaties and other sources of international law can be maintained. A primary purpose of the Organization is "to maintain international peace and security... and to bring about by peaceful means, and in conformity with the principles of justice and international law, adjustment or settlement of international disputes or situations which might lead to a breach of the peace." In the 
Universal Declaration of Human Rights established in 1948 , it is recognized that, “... it is essential, if man is not to be compelled to have recourse, as a last resort, to rebellion against tyranny and oppression, that human rights should be protected by the rule of law...

The Charter reiterates that rule of law at the country level refers to the existence of the rule of law framework which starts with a written or non-written Constitution as the supreme law of the land. The Charter emphasizes that there should also be:

...a clear and consistent legal framework, and implementation thereof; strong institutions of justice, governance, security and human rights that are well structured, financed, trained and equipped; transitional justice processes and mechanisms; and a public and civil society that contributes to strengthening the rule of law and holding public officials and institutions accountable. These are the norms, policies, institutions and processes that form the core of a society in which individuals feel safe and secure, where legal protection is provided for rights and entitlements, and disputes are settled peacefully and effective redress is available for harm suffered, and where all who violate the law, including the State itself, are held to account.

At the international level, the Charter of the United Nation embeds the principle of rule of law when dealing with Country to Country relations. Also, the Declaration of Principles of International Law Concerning Friendly Relations and Co-operation Among States in Accordance with the Charter of the United Nations (United Nations, 2013) states in its preamble that,

Drawn from existing commitments in international law, the core values and principles of the UN include respect for the Charter and international law; respect for the sovereign equality of States and the principle of non-use or threat of use of force; the fulfillment in good faith of international obligations; the need to resolve disputes by peaceful means; respect for and 
protection of human rights and fundamental freedoms; recognition that protection from genocide, crimes against humanity, ethnic cleansing and war crimes is not only a responsibility owed by a State to its population, but a responsibility of the international community, the equal rights and self-determination of peoples; and the recognition that peace and security, development, human rights, the rule of law and democracy are interlinked and mutually reinforcing. Appropriate rules of international law apply to the Organization as they do to States.

A.V. Dicey who propounded the constitutional theory of rule of law principle wrote (Dicey, 1885):

It means, in the first place, the absolute supremacy or predominance of regular law as opposed to the influence of arbitrary power, and excludes the existence of arbitrariness, of prerogative, or even of wide discretionary authority on the part of the government. Englishmen are ruled by the law, and by the law alone; a man may with us be punished for a breach of law, but he can be punished for nothing else. It means, again, equality before the law, or the equal subjection of all classes to the ordinary law courts; the 'rule of law' in this sense excludes the idea of any exemption of officials or others from the duty of obedience to the law which governs other citizens or from the jurisdiction of the ordinary tribunals; there can be with us nothing really corresponding to the 'administrative law' (droit administratif) or the 'administrative tribunals' (tribunaux administratifs) of France. The notion which lies at the bottom of the 'administrative law' known to foreign countries is, that affairs or disputes in which the Government or its servants are concerned are beyond the sphere of the civil courts and must be dealt with by special and more or less official bodies. This idea is utterly unknown to the law of England, and indeed is fundamentally inconsistent with our traditions and customs. 
Dicey wrote his treatise in 1885 after a study on the English unwritten constitution in comparison with French constitutional law. The book entitled "Introduction to the Study of the Law of the Constitution" discusses the supremacy or rule of law and what it meant in relation to England's unwritten constitution. Janet Munro-Nelson was of the view that "although the term "rule of law" can be found as far back as mid-300 B.C. in the writings of two Greek philosophers, Plato and Aristotle, contrasting the rule of law with the rule of man, it was Dicey who revived and discussed the term in such a way that everyone could understand it" (Munro-Nelson, 2008). Dicey's Rule of Law focuses on the following core principles:

1. Any person can be punished only if there is a law that makes his/her action illegal or unlawful by a court of law. Dicey opposed any form of arbitrary decision via discretionary power. He said, "with discretion come arbitrariness.'

2. That all persons are equal before the law and no one person is above the law. Dicey expounded the equality before the law principle out of concern about exemption of certain group of people from court and tribunal such as the immunity for the sovereign.

3. He argued that because of its Constitution being unwritten, rights and personal liberties are always secured compared to countries that have written constitution. He elaborated that the United States and written constitutions containing the Bill of Rights but without secured remedies for breach of the same. Dicey was not accurate in this respect because both rights and liberties in France and the US are secured by remedies provided by the Supreme Court. However, it has to be emphasized here that Dicey's formulation on rule of law iterates the importance of rights and personal liberties.

J. Munro-Nelson concluded that the three concepts of "rule of law" as set out by Dicey demonstrate a much deeper and broader definition than my definition of the term does. "Rule of law" seems to describe the parameters of the law and how the legal system upholds the law (Munro-Nelson, 2008).

Why rule of law? Ronald Dworkin in his keynote speech observed that everything else depends on the rule of law; a functioning economy, a free and fair political system, the development of civil 
society, public confidence in the police and the courts (Dworkin, 2012). Nonetheless, Dicey's formulation is fraught with difficulty. He referred to Joseph Raz who opined:

“...that a non-democratic legal system, based on the denial of human rights, on extensive poverty, on racial segregation, sexual inequalities, and religious persecution may, in principle, conform to the requirements of the rule of law better than any of the legal systems of the more enlightened Western democracies ... It will be an immeasurably worse legal system, but it will excel in one respect: in its conformity to the rule of law ... The law may ... institute slavery without violating the rule of law." (Dworkin, 2012)

The International Bar Association (IBA) in this respect observed (Kirby, 2010):

All countries, even those governed by the crudest dictatorship, need or have laws, although they disregard the individual or collective rights of all or parts of the population. Indeed, apartheid was enforced with meticulous attention to legal form and detail.

Dworkin surmised that Raz's formulation was however rejected by many scholars and on this he referred to Lord Bingham who said that:

"I would roundly reject [Raz's view] in favour of a 'thick' definition, embracing the protection of human rights within its scope. A state which savagely represses or persecutes sections of its people cannot in my view be regarded as observing the rule of law, even if the transport of the persecuted minority to the concentration camp or the compulsory exposure of female children on the mountainside is the subject of detailed laws duly enacted and scrupulously observed." (Dworkin, 2012).

In the context law-making, Raz's hypothesis supports the view that legitimacy in legislative power does not depends on whether the law that is passed in consonant with the principle of human rights and 
liberties or otherwise. It depends whether the legislative process is fully observed. The same argument is held by the positivist school of thought such as John Austin that law is what legislature has passed in accordance to its legislative procedure. Thus, Dicey's insistence on legitimacy via legislative authority consistent with the Constitution prevents law that is abusive of rights and liberties. The recognition of the needs to have bill of rights negate the formulation of principles based on whim and fancies of authority in power.

Lord Bingham reconstruction of the Dicey's rule of law, postulating eight sub-requirements, namely, (Kirby, 2010):

(1) The law must be accessible and, so far as possible, intelligible, clear and predictable;

(2) Questions of legal rights and liabilities must ordinarily be resolved by application of the law and not by the exercise of discretion;

(3) The law must apply equally to all, except to the extent that objective differences justify differentiation;

(4) The law must afford adequate protection of fundamental human rights;

(5) Means must be provided for resolving, without prohibitive cost or inordinate delay, bona fide civil disputes which the parties themselves are unable to resolve;

(6) Ministers and public officials at all levels must exercise the powers conferred on them reasonably, in good faith, for the purpose for which the powers were conferred and without exceeding the limits of such powers;

(7) Judicial and other adjudicative procedures must be fair and independent; and

(8) There must be compliance by the state with its international legal obligations.

Sir Michael Kirby went on to refer to the IBA resolution in 2009 that declared twelve sub-rules that were implicit in the very concept of the rule of law, namely, (Kirby, 2010):

(1) The existence of an independent, impartial judiciary;

(2) The presumption of innocence in the case of criminal accusations; 
(3) The prerequisite of fair and public trials, conducted without undue delay;

(4) The observance of a rational and proportionate approach to punishment of those who are convicted of crimes;

(5) The existence of a strong and independent legal profession;

(6) The strict protection of professional secrecy and of confidential communications between a lawyer and client so as to build confidence in the administration of justice;

(7) The maintenance of equality of all before the law;

(8) The absence of arbitrary arrests and secret trials;

(9) The absence of indefinite detention without trial;

(10) The exclusion of cruel and degrading treatment or punishment;

(11) The absence of intimidation and corruption both in the electoral and in judicial and other adjudicative decision-making; and;

(12) The conduct of governance in society through open and transparent institutions, with procedures and freedom of information, opinion and expression as prerequisites for operation of all of the foregoing characteristics.

Sir Michael Kirby went on to conclude that "the notion of the rule of law and the prerequisites elaborated successively by Dicey, Bingham and the IBA are essential to civilized modern governance" (Kirby, 2010). He then referred to Professor Anne-Marie Slaughter in the United States who suggested that Lord Bingham was right in prescribing the rule of law as "a fundamental bargain between the individual and the state, "the governed and the governor", in which both [parties to the compact] accept constraints for the sake of the common interest and the common good" (Kirby, 2010).

\section{Good Governance and Rule of Law}

How good governance is maintained by the rule of law? As one of the characteristics of good governance, rule of law plays a pivoting role. Rule of law provides legitimacy and authority to the government. Rules and regulations provide the framework for action and decision making process. As said umpteen times, without rule of law, the quest for good governance will never be successful.

The World Justice Project on Rule of Law (WJPROL) conducts annual survey on the state of rule of law in many countries including Malaysia. The areas covered by the survey include order and 
security, fundamental rights, effective criminal justice, absence of competition, clear, publicized and stable laws, regulatory enforcement and access to civil justice system. The 2012 survey results for Malaysia are as follows:

\begin{tabular}{lcccc}
\hline \multicolumn{1}{c}{ Factors } & Scores & $\begin{array}{c}\text { Global } \\
\text { Rankings }\end{array}$ & $\begin{array}{c}\text { Regional } \\
\text { Rankings }\end{array}$ & $\begin{array}{c}\text { Income Group } \\
\text { Rankings }\end{array}$ \\
\hline Limited Government Powers & 0.57 & $45 / 97$ & $8 / 14$ & $11 / 30$ \\
Absence of Corruption & 0.69 & $28 / 97$ & $7 / 14$ & $4 / 30$ \\
Order and Security & 0.86 & $16 / 97$ & $6 / 14$ & $1 / 30$ \\
Fundamental Rights & 0.50 & $73 / 97$ & $11 / 14$ & $22 / 30$ \\
Open Government & 0.48 & $48 / 97$ & $9 / 14$ & $15 / 30$ \\
Regulatory Enforcement & 0.52 & $46 / 97$ & $7 / 14$ & $15 / 30$ \\
Civil Justice & 0.57 & $39 / 97$ & $7 / 14$ & $8 / 30$ \\
Criminal Justice & 0.61 & $31 / 97$ & $7 / 14$ & $3 / 30$ \\
\hline
\end{tabular}

Source: www.worldjusticeproject.org/country/Malaysia

Overall, Malaysia is in the mid-table amongst 97 countries. Malaysia is quite low in the score on fundamental rights and open government whilst is fairly average in the other aspects of rule of law. As far as Asian countries are concerned the World Justice Project on Rule of Law survey conducted in 2012 has shown that majority of Asia and Pacific countries are in the below 20 categories in rule of law practices accept for countries like Australia, New Zealand, Hong Kong and Singapore (WJPROL, 2012). The overall low scores for most of the countries was due to the following; delays in the justice system; high cost of litigation, corruption, long and arduous legal process; low public confidence in the system, unmet contractual obligations, unfair disputes settlement process, fragmentation of judicial system, low funding support and archaic law that is unresponsive to changing environment.

Another contribution to it is weak law enforcement due to resource constraint, low salaries, unfilled vacancy because of unrealistic qualification and backlog of cases in court. Many steps are taken by the affected countries in overcoming the problems but alternative dispute settlement (ADR) need to be introduced and success has been shown in Singapore after adopting the compulsory ADR in the case management process in the court of law. As far as corruption 
is concerned, the effective method of enforcement in dealing with corruption in Hong Kong needs to be studied to consider adopting them in the respective country anti-corruption machinery.

One method of ensuring good governance is ensuring citizen participation in the governance process. It does not mean that the government must consult each and every citizen for every policy and decision to be made. Participation in good governance means that citizen has easy access to official information; there is an ongoing government policy to promote transparency and continuous programs of engaging the public via public forum such as town hall meetings. Freedom of Information bill should be seriously considered by countries in Asia that will provide the legal route for citizen to obtain government documents.

Thus, in strengthening rule of law, enhancing enforcement including anti-corruption enforcement, the prosecuting body and the court is of utmost importance. This also includes improving investigative abilities of law enforcement agencies, for instance forming or improving forensic sciences by establishing forensic laboratory. A review of rules on preliminary investigations is also apt as it is a crucial part in any successful prosecution of criminal cases especially those involving corruption.

Human Rights Commission has been the trend in most Asian countries especially after the worldwide economic crisis of 1997. Malaysia has introduced its own commission in 1999 with the establishment of the Human Rights Commission of Malaysia (SUHAKAM) under the Human Rights Commission of Malaysia Act 1997 (SUHAKAM, 2013). Section 4, among others, states that SUHAKAM functions to promote awareness about human rights; to inquire on human rights abuse; to advise the government on legislation that affects human rights; to advise the government on subscribing to relevant international convention on human rights and to recommend for action against person and institution for human rights abuse.

This is well and good but the impending issue is how effective is the commission in safeguarding human rights and upholding rule of law. How independence is the body and the extent to which that they are not in consonant with any political party and in cohort with the government of the day? Therefore, any human right commission 
must not be a toothless tiger and they should not be the tool of any political party or body to serve their own motive and purpose. Thus, Malaysia's SUHAKAM should be given clouts to ensure that its recommendation should be effectively implemented. Also, to ensure that it is directly accountable to Parliament and its report is tabled in Parliament.

Thus, taking into account of postulates of rule of law by Lord Bingham and the IBA, it can be hypothesized that the very elements of good governance is the characteristics of rule of law itself. The pairing and connection between good governance characteristics and the postulates of rule of law can be shown as follows:

\begin{tabular}{|c|c|c|}
\hline & $\begin{array}{l}\text { Elements } \\
\text { of Good } \\
\text { Governance }\end{array}$ & Rule of Law Postulates \\
\hline 1 & Accountability & $\begin{array}{l}\text { 1. Ministers and public officials at all levels must exercise } \\
\text { the powers conferred on them reasonably, in good faith, } \\
\text { for the purpose for which the powers were conferred and } \\
\text { without exceeding the limits of such powers; } \\
\text { 2. Judicial and other adjudicative procedures must be fair } \\
\text { and independent; } \\
\text { 3. Means must be provided for resolving, without prohibitive } \\
\text { cost or inordinate delay, bona fide civil disputes which the } \\
\text { parties themselves are unable to resolve; }\end{array}$ \\
\hline 2 & Transparency & $\begin{array}{l}\text { 1. The law must be accessible and, so far as possible, } \\
\text { intelligible, clear and predictable; } \\
\text { 2. Questions of legal rights and liabilities must ordinarily be } \\
\text { resolved by application of the law and not by the exercise } \\
\text { of discretion; } \\
\text { 3. Judicial and other adjudicative procedures must be fair } \\
\text { and independent; }\end{array}$ \\
\hline 3 & Responsive & $\begin{array}{l}\text { 1. Questions of legal rights and liabilities must ordinarily be } \\
\text { resolved by application of the law and not by the exercise } \\
\text { of discretion; }\end{array}$ \\
\hline 4 & $\begin{array}{l}\text { Equitable and } \\
\text { inclusive }\end{array}$ & $\begin{array}{l}\text { 1. The law must apply equally to all, except to the extent that } \\
\text { objective differences justify differentiation; } \\
\text { 2. Ministers and public officials at all levels must exercise } \\
\text { the powers conferred on them reasonably, in good faith, } \\
\text { for the purpose for which the powers were conferred and } \\
\text { without exceeding the limits of such powers; }\end{array}$ \\
\hline 5 & $\begin{array}{l}\text { Effective and } \\
\text { efficient }\end{array}$ & $\begin{array}{l}\text { 1. Means must be provided for resolving, without prohibitive } \\
\text { cost or inordinate delay, bona fide civil disputes which the } \\
\text { parties themselves are unable to resolve; }\end{array}$ \\
\hline 6 & Participatory & $\begin{array}{l}\text { 1. The conduct of governance in society through open and } \\
\text { transparent institutions, with procedures and freedom of } \\
\text { information, opinion and expression are prerequisites for } \\
\text { operation of all of the foregoing characteristics. }\end{array}$ \\
\hline
\end{tabular}




\section{Corruption and Good Governance}

One aspect of activities that have serious implication in undermining good governance is corruption. There are many reasons for corruption to thrive. Opportunity, weak legal framework and weak enforcement is usually the main reasons. However, one cannot hypothesize that these are the only reasons. Culture and political traditions could also allow corruption to be unabated. The study in the Philippines suggested that there is a culture of corruption deeply ingrained in the society due to the dominance of elite interests in local and national politics (PDP, 2011). There is also lack of accountability on the ruling political party based on principled party platforms. This is further exacerbated by weakness and subservient of bureaucracy to political class. Corruption could also caused by large discretionary power being conferred to the executive either by law and practice and this encourages political patronage and grand corruption (PDP, 2011).

Malaysia has taken many steps to eradicate corruption especially by enhancing the power of the enforcement agency, the Malaysia AntiCorruption Commission (MACC). The anti-corruption laws started in 1961 with the Prevention of Corruption Act 1961. The AntiCorruption Agency (ACA) was established in 1967. Significantly in 1997, the Act was transformed to Anti-Corruption Act 1997 that was supposed to fight corruption more comprehensively, employing multifarious means. Noor Alam Siddiquee observed (Siddiquee, 2001):

Since its establishment the ACA has adopted a comprehensive approach where a myriad of tools and strategies are applied. Three key components of ACA's strategy are education, prevention and enforcement. The education strategy focuses on efforts to inculcate ethical values among members of the public and the civil service so as to create a sense of abhorrence and intolerance towards corruption. Increasing emphasis is placed on building rapport with the community and enlisting their support in the fight against corruption. To this end, besides educating younger generations at schools and other educational institutions Combating 
Corruption and Managing Integrity in Malaysia aimed at inculcating noble and ethical values among them, the ACA conducts dialogues, public campaigns and seminars to explain anti-bribery laws, and encourage the community to take corruption prevention measures and come forward to report to ACA on corruption cases. Since prevention is seen as a major strategy to combat corruption, the ACA has been active in the area of tightening laws and procedures, with a view to enhancing the deterrence of its anti-corruption measures.

In 2009 the law on ACA was amended and the structure transformed to become a Commission modeled after Hong Kong anti-corruption agency with two independence bodies overseeing as well as to serve as checks and balances mechanism to monitor the functions and roles of MACC (MACC, 2013). The Anti-Corruption Advisory Board consisting of independent non-partisan persons who have distinguished public services or who have achieved distinction in their profession. Secondly, Special Committee on Corruption, who are across party representatives of the House of Representatives and House of Senate which function to monitor MACC and give advice to the Prime Minister. Three other committees are the Complaint Committee to hear and decide complaints against MACC officers on non-criminal misconduct; the Operation Review Committee whose members are experts to review MACC strategies and operations and provide suggestions for improvements; and the Corruption Prevention Panel whose members are amongst academic, NGOs and the industry to recommend for programmes to inculcate hatred against corruption. Most significantly is the measure carried out by PEMANDU to include Anti-corruption measures as part of the National Key Results Area (NKRA) projects. The initiatives include:

1) 'Name and shame' which involves a special list of convicted corruptors are uploaded into the MACC website with the objectives of providing additional deterrence as names would be publicly available and may have impact to potential business ventures and future employers.

2) 'Hot job rotation' refers to identifying 'hot staff' who is doing 'hot job' and the need to transfer them within or outside 
the department after he/she has served for certain period to prevent the officer from gaining or benefit illegally from his/ her position. 'Hot job' is job that is vulnerable to corrupt practices such as licensing or permit section of a government department.

3) Prosecution of corruption cases within one year after it has been reported. This is based on the study that cases that were prosecuted more than a year have high probability of nonconviction because of witness fading memory, witness missing or turning hostile or passed away. The Criminal Procedure Code was also amended to speed up trials by introducing pretrial conference for plea bargaining and smoothen trial; 14 Session courts were formed and senior officers were appointed to deal with prosecution of corruption cases.

4) The promulgation of the Whistleblower's Protection Act 2010 is to combat corruption and other wrong doings by encouraging and facilitating disclosures of improper conduct in the public and private sectors, to protect persons making disclosures from detrimental action, to provide for the matter disclosed to be investigated and dealt with and to provide remedies connected therewith. The Act covers disclosures for abuse of authority, violation of laws and ethical standards, danger to public health or safety, gross waste, illegality and mismanagement.

In overcoming corruption and perhaps to reduce incidents of corruption and at the same time enhancing governance in public administration, the following measures can also be taken (PDP, 2011):

(a) Intensifying efforts to detect corruption that involve a special committee or an action group to study trend and incidents of corruption and finding ways to tackle them at root level.

(b) Unresolved pending cases have impact on confident of the judicial system and the prosecution services thus measures to improve the process would enhance the fight against corruption.

(c) A comprehensive anti-corruption program including advocacy programmes would have to be in place that includes campaign and enculturation of anti-corruption ethos amongst the community including school children. 
(d) Law is the best mechanism to reduce corruption but sometime the legal and policy framework need strengthening especially the enforcement part and that could significantly enhance corruption prevention.

(e) International cooperation could enrich experience of local enforcement agencies through consultancy and training programmes funded by international agencies as well as programmes conducted by enforcement agencies in the more advanced Asian countries and Europe.

(f) Besides creating key result areas (KRA) for specific agencies to achieve, there should be a comprehensive and integrated framework and programme that include providing anchoring of the strategic objectives to focus on achieving its KRA. The starting point is a comprehensive and integrated process of prosecution and conviction; and ancillary programmes such as freezing and seizure of assets and recovery of property where priority is given to high profile cases.

(g) The overall review includes review of all efforts by enforcement agencies in anti-corruption activities that cover all aspects of functions such as efficiency, shortfalls and standard operating procedures. Inter-agencies channel of communication also need to be strengthened.

(h) Private sectors role should be enhanced in anti-corruption measures where programme can be held to seek their supports such as that of the chamber of commerce and association of manufacturers and producers. This should also include improving line of communication with them.

(i) One high risk area susceptible to corruption is public procurement processes. This area needs tremendous improvement to reduce corruption and electronic process in procurement has helped substantially to prevent corrupt activities.

(j) Public involvement through NGOs and interest groups in reviewing anti corruptions measures may encourage a more open discussion on corrupt practices and sowing seed of hatred toward such activities.

Malaysia is serious in fighting corruption. The Corruption Perception Index (CPI) by the Transparency International (TI) is taken seriously. Malaysia has improved its standing from 60th in 2011 to 54th in 
2012 amongst 176 countries surveyed by TI. Measures taken by establishing a Commission and appointing independent advisory board and parliamentary committee to oversee its functions and duties and most significantly imposing an anti-corruption agenda as part of NKRA initiatives have definitely gained confidence of both locals and foreigners alike. In announcing Malaysia's CPI result for 2012, TI Malaysia's President, Paul Low said in a press conference (The Star, 12 June 2012):

The improvement is expected...all the efforts and steps taken by the government, the Malaysian Anti-Corruption Commission (MACC) and Pemandu (Performance Management \& Delivery Unit) have borne fruit and we hope that Malaysia will manage to break records.

\section{Independence of the Judiciary}

As good governance requires an effective mechanism of law enforcement, that is further supported by judicial independence as the bedrock of rule of law. Honourable Chief Justice of Malaysia, Tun Arifin Zakaria in a lecture at the Malaysian Institute of Integrity referred to Lord Woolf who said (Arifin Zakaria, 2010):

"One of the most important of the judiciary's responsibilities is to uphold the rule of law, since it is the rule of law which prevents the government of the day from abusing its powers. Ultimately, it is the rule of law which stops a democracy descending into an elected dictatorship. To perform its task, the judiciary has to be, and seen to be, independent of government, unless the public accepts that the judiciary are independent, they will have no confidence in the honesty and fairness of the decisions of the courts."

The Honourable Chief Justice of Malaysia went a step further by saying that judiciary must not only be independent but must seen to be independent (Arifin Zakaria, 2010). This, he said is a matter of public perception and this has to be dealt with effectively. He further emphasized that independence is at two levels; individual and institutional. The learned Chief Justice opined that (Arifin Zakaria, 2010): 
At the individual level, a judge should always act with integrity and independent. As guidance, Part 3 of the Judges Code of Ethic 2009 sets out the code of conduct that judges have to adhere to. Section 5 of the Judges Code of Ethic 2009 provides that a judge shall exercise his judicial function independently on the basis of his assessment of the facts and in accordance with his understanding of the law, free from any extraneous influence, inducement, pressure, threat or interference, direct or indirect from any quarter or for any reason.

Students of Malaysian Constitutional law would be very familiar about Part 9 of the Federal Constitution dealing with provisions in ensuring judicial independence, namely, the appointment process, judges' remuneration, and security of tenure, judicial conduct, and judicial code of ethics. Most recently, the Judicial Commission Act was promulgated with an important section 2 on judicial independence that states:

The Prime Minister must uphold the continued independence of the judiciary and must have regard to-

(a) The need to defend that independence;

(b) The need for the judiciary to have the support necessary to enable them to exercise their functions;

(c) The need for public interest to be properly represented in regards to matters relating to the judiciary, the administration of justice and related matters.

It is now an express provision in a statute that put the responsibility on the Prime Minister to uphold the independence of judiciary. The Act has improved the process of judicial appointment (Article 122) with the establishment of the Judicial Appointment Commission (JAC). $\mathrm{JAC}$ is to recommend to Prime Minister who would then advise the Yang di-Pertuan Agong to make the appointment (Arifin Zakaria, 2010). The Commission who is chaired by the Chief Justice also recommends promotion of judges and in this respect Honourable Chief Justice remarked that, "I can assure you that the selection of judges is based entirely on merit, though, for promotions, seniority is also taken into account. It is done through secret ballot." (Arifin Zakaria, 2010). 
Article 125 of the Federal Constitution provides for judges' security of tenure that includes; judge's removal shall be by a specially constituted tribunal by the Yang di-Pertuan Agong. The tribunal was formed twice to recommend removal of judges. The Constitution also provides that conduct of judges shall not be discussed in Parliament unless with a substantive motion by members of Parliament at the House of Representative. Section 14 of the Courts of Judicature Act 1964 gives judges immunity from all civil liabilities in the exercise of their judicial function. Judges' remuneration is charged in a consolidated fund and shall not be altered to judges' disadvantage as in Article 125(6) and (7).

Independence is of no meaning if the efficiency of the system is questionable. Continuous review of the system is essential that covers various aspects that include cost of litigation that has great impact toward access to justice. The judiciary core stakeholders, judges and judicial commissioners as well as officials need to be subject to continuous improvement programme to enhance their knowledge and skill. The use of technology should be seriously planned for as technology has led to speedier judicial process in countries like Singapore that had introduced the use of online court process. Country needs to spend and provide more resources to improve overall performance of enforcement officers and judicial staffs. Corrupt and undesirable officials must be weeded out from the system where strict enforcement of disciplinary measures must be taken against them. Code of conduct especially for judges provides the required legal and ethical framework for them.

Judicial independence requires constitutional guarantees. This has been the situation in Asia as most of them have adopted the continental form of constitutional scheme and the minority Asian countries have followed the Common Law approach. Be it as it may, constitutional guarantees must include security of tenure for judges, protection from any form of interference, clear code of conduct, guaranteed remuneration, sufficient infrastructure and efficient system of administration of the court.

\section{Access to Justice}

Good governance would also mean that ordinary citizens can have their day in court with ease without worries about having to pay the 
high cost of litigation when they cannot afford to pay for it. Access to justice is also part of the rule of law. If a citizen cannot go to court because they don't have the means to do so, it amounts to serious deprivation of right. This is where legal aid plays significant role in ensuring that the poor can obtain justice in court and their rights are protected by the judicial system. The Legal Aid Act 1971 is however provides very limited scope of aids in legal matters. In civil matters, it covers family law and Shariah family law matters and limited types of civil litigation such as under the Workmen's Compensation law, hire purchase law and road accident cases. In Criminal litigation it covers accused who is unrepresented in court who pleaded guilty and is to make plea in mitigation. It also covers criminal proceedings under the Child Act 2001 and under the Minor Offences Act 1955.

Awareness and education of their legal rights is part of access to justice. It is the duty of the state to expose its citizen to their rights and obligations under the law. A solid and wide legal aid scheme requires the manpower and financial resources and this is where many Asian countries cannot afford to provide. In this respect alternative mechanism can be brought forth such as tax incentives for lawyers who give pro bono legal services and making it compulsory for young lawyers to provide their services via the government legal aid scheme where standard emoluments will be provided for them. In many Asian and African countries, non-governmental organizations together with volunteering paralegals assist members of the public in providing free legal aid.

Delay in judicial remedy is an antithesis to access to justice. Alternative Dispute Resolutions (ADR) is known to be speedier and that assist in enhancing access to justice. ADR is a decision making process minus the combative element in the judicial process. Arbitration, mediation and conciliation end with a win-win situation that is advantages to the disputing parties. Except for business transaction, the cost for ADR can be cheaper in family law disputes and small and medium civil claims (private law matters). By promoting ADR, backlog of cases in the courts may be substantially reduced. Singapore has made ADR compulsory for the civil claims and it has been shown that cases are resolved faster in that manner even before it goes to trial. Indirectly, it helps to reduce cost of litigation (PDP, 2011). 


\section{Freedom of Information (FOI) and Citizen's Participation}

Citizen's access to information and participation in governance serve to include inclusiveness and participatory aspect in good governance. The right of information is always been denied in most Asian countries due to restrictive law on confidential information. In Malaysia for instance, the Official Secrets Act still follow the old English law that make official information labeled secret and confidential by the government to be publicly restricted and exposing them an offence under the Act. Whilst the Law in England had changed and Freedom of Information law was introduced, access to public document and information remain extremely difficult in Malaysia even for academic research purpose. The same can be said to other Asian countries as well.

With the FOI, government decision making process will be more transparent and access to information will be more organized and structured. Citizen may request for information through appropriate channel and payment of minimum fee. Survey and statistics can be easily obtained and that make government decision making more clear and transparent. Critic of government policies may be able to make a more informed comment and criticism. Budgetary and public expenditure are available to the general public and the reality of fiscal and economic situation is within the public sphere.

It is now the good practice in many countries in Asia where their annual budget report is published to allow the public to view them and availability in the official website has made them more accessible to the masses. It is also interesting that many governments in Asia have the common practice of giving opportunity to the public to participate in preparation of annual budgetary presentation in Parliament through public forum and town hall meetings. In Malaysia, the Ministry of Finance invites individual and group to submit their proposal to be considered by the government in preparation for its annual budget presentation in parliament at the end of month of October.

Besides the FOI bill, a citizen's independent committee funded by the government on public policy and decision making should be established. It serves as an official and recognized platform 
for ordinary citizen to give feedbacks on government policy and decision and also to suggest changes to existing law and policy that affect the citizen's welfare and the country as a whole. There should be however, an open and transparent search process in the selection of appointees in this committee as practiced in the Philippines (PDP, 2011)

\section{The Overall Approach in Good Governance}

The Philippines Development Plan (PDP) indentified ten strategies to promote governance, namely, (PDP, 2011):

1. Ensure high-quality, efficient, transparent, accessible and non-discriminatory delivery of public service. This requires knowledgeable and experienced staffing that is acquired through exposure and training as well as good infrastructure and adequate budgetary support.

2. There should be time limit for disposal of corruption cases and this should be made as key performance indicators (KPI) for enforcement agencies.

3. Curb both bureaucratic and various legal and political corruption. For whatever term is used, corruption has to be fought through legal and non-legal means.

4. The judiciary is independence and this is ensured via constitutional provisions. There should also be clear path for citizen's access to legal recourse and sufficient access to legal aid and pro bono legal services.

5. Citizen access to information is enhanced through law and policy on freedom of information. There should be timeline for the introduction of Freedom of Information Bill.

6. The Philippine's development plan (PDP, 2011) argues that policy and guidelines on elements and parameters of probable cause of corruption should be issued based on law and jurisprudence to avoid frivolous filing of cases and to reduce rate of unsuccessful prosecution in court.

7. The court procedures play an important role in expediting cases and this area needs to be given special attention. The procedures must be strictly observed and yet there should also be room for discretion in the court to expedite cases. Evidential rules are essential but the prosecution must ensure 
that all instruments to gather evidence are utilized. There should be regular exercise of rules review to expedite trials and provide quick resolution to cases.

8. A comprehensive anti-corruption program should include a single body that deals with the offence and even if there are many bodies involved, a coordinating authority should be in place. The coordinating body should provide seamless investigation pathway between various enforcement authorities (PDP, 2011). There should also be a regular review of conviction rate; review of case management and monitoring progress of cases.

9. There should also be effort to gain knowledge from international experiences from bodies in other countries and to participate in multi-national programmes organized by the United Nation, OECD, Asian Development Bank and the World Bank.

10. The public should be encouraged to contribute to eradication of corruption by creating various reporting mechanism that is easily accessed by them such as online reporting and direct and free telephone services to the authority. A whistleblower charter or legislation will be a tremendous booster for this programme.

The Plan further added that a comprehensive action plan will have to be in place that goes hand in hand with the abovementioned goals and this includes (PDP, 2011):

a. Integrating services according to the needs of the citizens. This will cover aspects of efficiency and accountability as well as comprehensiveness of public services. This also includes accessibility, speed, transparent and customer friendly services. Priority should be for services that provide for welfare and security of the citizen.

b. Enhancing the transparency of government transactions. Public projects are the most vulnerable of all to corrupt practices and abuse of public power such as cronyism and favoritism. Thus, transparency and clear procedure on tendering rules and process must exist. Where direct negotiation to award public project is to be made, agreed criteria and clear qualification 
for appointment should be in place. Thus, close scrutiny to ministers and officials who have direct authority over these transactions must be exercised such as the requirement to declare own and close family member's assets.

c. Making government focus on its core functions. There is tendency in modern government to be actively involved in business that in a way has affected its focus on the core function such as eradication of poverty and providing good healthcare services to its citizen. Creation of government linked companies/corporations (GLCs) can positively contributed to the nations' economy but most of these entities are poorly managed and has caused substantial losses to the government. There are also government which spent a substantial amount of its annual budget in defense and procurement of arsenals and weaponries at the expense of education, health and welfare.

d. Standardizing the quality of public service delivery. Delay, poor services and incompetent officials are the common complaints as far as delivery of services is concerned. There should be citizen's charter in every department of the public service. It serves as a promise of good and efficient services to the public. Service improvement should be part of the departmental strategic agenda. An annual customer satisfaction survey should be conducted to gauge public perception on the overall service delivery. This should include "devising a communication management tool and methodology to solicit citizen's feedback" (PDP, 2011).

e. Improving financial management system in government. This is where the role of the Auditor General Office is substantially significant. The annual audit report includes wastages and misused of public fund. It would also detect corrupt practices and abuse of power. The concern is always the aftermath of the report and the extent to which, named and unnamed officials are taken to task by the respective department and disciplinary and in some cases criminal action is taken against them. Recently, the Malaysian Auditor General expressed his regret that action had not been taken against public servants who had been proven to have misused their power and failed to comply with financial rules as reported in the annual Auditor General report. 
Malaysia has more or less implemented most of these plans to ensure smooth and efficient public service process and service delivery but certainly there are measures that are still in planning stages. Freedom of information is one of them and in the light, a law on FOI should be seriously considered. The other aspect is access to justice. Malaysia is one of the few Asian countries that do not provide free legal aid for those charged with criminal offences except at the time of mitigation. Undoubtedly, legal aid is extremely expensive but without sufficient legal aid, needy people would not able to have a just and fair day in court and thus justice is denied to them.

\section{Public Governance and Private Governance}

Corporate governance is the structure by which the shareholders, through its board and management, set objectives, determine the means for achieving them and monitor actual performance of the company (Chhikara, 2001). As the corporate world reeled from the scandals that hit various multinational companies in the early $21^{\text {st }}$ century such as BCCI and recently the Omron saga, regulators in many countries had sought to strengthen governance in companies by introducing rules and code of corporate governance. As much as the public sector governance can learn from corporate governance, private sector governance may apply various principles that public governance have successfully applied. Chhikara argued that good public governance are political stability, accountability of officials, effectiveness of government, quality of regulatory framework, rule of law and control of corruption (Chhikara, 2001). These factors have been elucidated earlier in this paper. He went on to say that failure in corporate governance system contributed to the Asian financial crisis and reforms are essential to restoring the region's economic growth.

A study by Deloitte (2006) on the middle-east public governance concluded that there was a great deal of awakening in those governments to promote high level of accountability and transparency in the public sector. In that respect, various aspects of good governance principles such as performance, accountability, transparency, efficiency, leadership, ethics and integrity, organizational structure and process and strong internal control that include risk management and business continuity are adopted. Some 
of these principles are already ingrained in corporate governance structure, and thus, adopting a culture that private sector is familiar with into the public sector (Deloitte, 2006).

On the other hand it has been argued that corporate governance can learn from public governance in the sense that institutions devised to control and regulate the behavior of actors in the public sphere can give new insights into how to improve the governance of firms (Benz and Frey, 2007). They suggested four cornerstones of public governance that be applied in corporate governance namely; realigning managers' compensation with the practice prevalent in the public sector such as fixed compensation and not dependent on pay-for-performance. Secondly, the public governance's democratic idea of division of power in corporate governance. Thirdly, rules of succession which is prevalent in political sphere can be devised in the corporate sector. Fourthly, corporate governance can be improved by relying on institutionalized competition in core areas of the firm.

Public and private sector governance in essence share some basic common characteristics but it is the context in which they are embedded that drives the differences (Armstrong, Jia, Totikidis, 2005). They suggested in ten areas that the two are separated namely, organization structure; regulation; agents; objectives; origin of governance model; authority; responsibility; independence; accountability and reporting. There are also similarities such as private sector managers are agents of the shareholders to oversee the day-to-day management of the company; while the public servants are acting as agents of the tax payers to manage the public organization for the purpose of serving the best interest of the general public (Armstrong, Jia, Totikidis, 2005). The writers summarized that (p. 10):

...there is a parallel development of governance arrangements in both the public and private sector. Those parallels suggest that governance issues have indeed become an intrinsic part of good management of both the public and private entities. Adopting the same basic good corporate governance standards, the public sector and the private sector developed (in parallel) each own unique governance models, practices and 
mechanisms that suit each individual organization's circumstances. The adopting of good governance and basic standards across the board will also help the public sector and the private sector to learn from each other the best practices in each sector and help to improve governance in the future.

There are at least two propositions that can be brought forth from the above. First, both governance types have rule of law that bind the good governance principles together. Second, corruption which is the cause of bad governance happened mainly because of the collusion between the public sector and private sector. If rule of law is broken or weak, both governances would collapse. Similarly, if both the public and private sectors failed to halt the evil of corruption, the goal of achieving good governance would fail. The regulators are the government and the legislature. However, political will and expediency plays a pivotal in charting the type of governance that the country would have. This is indeed very important because if the anticorruption law is lagging and the enforcement is lackadaisical, the development of ethos in achieving good governance will be stunted.

\section{An Islamic Perspective of Good Governance}

God governance is a culture that makes people act responsibly, thoughtfully and conscientiously (Valliani, 2012). It also encourages people to act with restraint, avoid abuse of power, act within parameter of the law, and impersonal in the discharge of their duties (Valliani, 2012). Islam emphasizes that good governance is highly dependent to leadership in the administration. That is the core element and if leaders do not possess the required qualities, the administration would never achieve good governance. These required qualities include refinement, experience, alertness, and power of comprehending problems, secrecy, freedom from greed and lust and personal attributes (Abbas, 2013). Personal character is also the key to good governance. Leaders must be honest, trustworthy, fair, friendly, firm and persons with strong personality.

Islam considers that the aims of good governance are to achieve social and economic justice (Abbas, 2013). Social justice refers to basic rights such as food, shelter, health services and education. 
These are the obligations of the government to its citizens because they have the rightful share in state resources and are bona fide citizens of the country (Abbas, 2013). While economic justice refers to equitable distributions of means of living and ensuring that wealth does not concentrate in any particular group or community in the society (Abbas, 2013). This reiterates the basic strategies of good governance that are honesty, efficient and accountable government. Abbas quoting Ibn Khaldun who said that a successful and viable administrative set up is that in which people's participation is ensured. If the governed feel that they share the administrative process, the society would be stable. Administration should be such as make people feel that they are equal partners in the process of planning, administration and implementation (Abbas, 2013). Participation is indeed emphasized as well in Islamic good governance and that augurs well with the concept of Shura (consensus) in Islam.

Reference is also made to the period of when Prophet Muhammad was the head of state in Medina. He drew up the Constitution of Medina that laid down the principles of good governance that included the rights of the non-Muslim of Medina. He created the bond of brotherhood among the Muslim citizens and upheld Islamic value system in which justice remains central (Valliani, 2012). Azram observed that (Azram, 2009):

He initiated good governance by introducing social reforms (such as imposing Zakat for the betterment of the depressed layers of the society, rescuing the poor from chronic debts, to improve the defence of the new-born city-state, allotting shares in inheritance to women, regulating marriage and divorce, prohibiting usury and so forth), along with the promulgation of religio-moral and spiritual teachings of the Qur'an (such as the exclusive worship of God alone, and a firm faith in eschatology, that is, the day of judgment and the life hereafter). When people witnessed Islam being translated in practice and a just socio-moral order established, they entered the fold of Islam tribe after tribe so much so that when the Prophet (SAW) died (in June 632 C.E.) he was virtually a prophet-ruler of the entire Arabian Peninsula. 
If we were to list down the principles of good governance in Islam, the principle of Amanah takes precedence based on the concept of vicegerent of man in this world. The Quran states, "betray not Allah and His Messenger, nor betray knowingly your amanah (things entrusted to you and all the duties which Allah has ordained for you" (Quran, 8:27). Secondly, as elaborated earlier, leaders must be sincere and have impeccable character (Valliani, 2012). Appointment of officials in the public service must be made on the basis of qualification and competency and good character and any form of elevation in post or promotion must be based on set performance criteria, honesty and integrity. It is stated in the Quran, "and that man can have nothing but what he does" (Quran, 53:59). What is not rightfully his is not what one can claim and in a hadith from Abu Daud, the Prophet was reported to have said that "he whom we have appointed for a job and have provided with livelihood, then whatever he appropriates beyond this is illegal".

The concept of taqwa is the other principle that is closely linked to good governance (Valliani, 2012). Taqwa is simply God-fearing. Every believer should be mindful of Allah's omnipresence and every act of man will be recorded. One should develop a sense of Allah's presence in his mind and heart (Valliani, 2012). If those who helm the administration lack taqwa in themselves, it would be catastrophe to good governance in administration. Corruption and abuse of power will thrive; the country will be weak and is opened to infiltration of sinister plot from internal and external forces. Rights will be trampled and integrity and rule of law will be affected. Allah has promised just ends for all deeds and for those who have breached the principles of vicegerent on earth, "And we have fastened every man's deeds to his neck and on the Day of Resurrection, We shall bring out for him a book he will find wide open" (Quran, 17:13). The 'book' in this verse refers to the recording of all deeds of man, be it good or bad; that serves as the evidence for him or against him on the Day of Judgment.

If one to compare Islamic principles of good governance with that of the conventional one; one would conclude that there are lots of similarities between the two concepts. Good governance is a concept that promotes good and just administration and with the 
goals of achieving public good. Corporate governance is the will of the shareholders whilst public governance reflects the will of the people as a whole.

\section{Conclusion}

From the foregoing, governance in itself is a structured principle. Good governance implores values from those that have the power to govern. As one of the values, rule of law is pivotal in ensuring fair, just and stable governance. Public and private governance apply the same values and principles and there is interconnectivity between the two. In fact they are intertwined and they are inter-dependent on each other for efficiency and effectiveness.

Corruption, a disease and an anti-thesis to the rule of law will have to be fought by both sectors. There is causes and effect in corruption that warrants intensive cooperation between the two sectors. As both sectors are the main players in corrupt activities, rule of law that governs them needed to be reviewed and strengthened and this has been the deliberation of the paper.

\section{Bibliography}

A.V. Dicey, The Study on the Law of the Constitution, 1885.

Anona Armstrong, Xinting Jia and Vicky Totikidis, 2005, "Parallels in Private and Public Sector Governance" www.viur.vu.edu. $\underline{\text { my/948/1/ }}$

Amin Valliani, 2012, "Islam on Good Governance" https://dawn. com/news/771164/islam-on-good-governance

Biro Bantuan Guaman Malaysia, www.bbg.gov.my

Cynthia Hewitt de Alcantara, "Uses and Abuses of the Concept of Governance" www.isites.harvard.edu/

Deloitte, "Public Governance in the Public Sector" www.deloitte. com 
Department of Justice Philippines, 2011, Philippines Development Plan 2011-2016, Good Governance and the Rule of Law http:// www.doj.gov.ph/files/pdf/2 PDP Good\%20Governance $\% 20$ and $\% 20$ the $\% 20$ Rule $\% 20$ of $\% 20$ Law.pdf

Janet Munro-Nelson, "Rule of Law: A Footnote in Time" http://the beacon.info/blog/wp-content/uploads/2011/05/RULE-OFLAW.pdf

Malaysia Anti-Corruption Commission, www.macc.gov.my

Michael Kirby, "The Rule of Law and the Law of Rules: A Semiskeptical Perspective" Malaysian Bar Association 15 $5^{\text {th }}$ Law Conference, Kuala Lumpur, July 2010.

Matthias Benz and Bruno S. Frey, "Corporate Governance: What can we learn from Public Governance?" Academy of Management Review, 2007, Vol. 32, No. 1, 92-104.

Mohamad Abbas, Good Governance in Islam "http://www.irfi.org/ articles/articles 351 400/good governance in islam.htm

Mohammad Azram, 2012, "Principles of Good Governance in Islam” http://irep.iium.edu.my/1834/

National Key Results Area against Corruption, www.nkracorruption. gov.my

Noor Alam Siddiquee, "Combating Corruption and Managing Integrity in Malaysia: A Critical Overview on Recent Strategies and Initiatives" Public Organization Review, 2010, 10:153-171.

Raj Chhikara, "Governance in Asian Countries: Problems and Issues" in Asian Development Bank Institute, Reforming Public and Private Sector Governance in Asian Countries, Executive Summary, 5-9 November 2001, Tokyo.

Tun Arifin bin Zakaria, "Rule of Law and Judicial System" Syarahan Perdana Integriti, Institut Integriti Malaysia, 2012. 
United Nations Economic and Social Commission for Asia and the Pacific, What is Good Governance? http://www.unescap.org/ pdd/prs/ProjectActivities/Ongoing/gg/governance.asp

United Nations, United Nations Rule of Law, "What is Rule of Law?" http://www.unrol.org/article.aspx?article id=3

World Justice Project on Rule of Law http://worldjusticeproject.org/ rule-of-law-index 